

\section{Daftar Isi (Table of Content) Journal of Government
Civil Society}

\begin{tabular}{|c|c|}
\hline \multirow{3}{*}{$146-163$} & $\begin{array}{l}\text { New Public Management (New Public Comparison Meta-Analysis } \\
\text { Developed and Developing Country Policies) }\end{array}$ \\
\hline & Dyah Mutiarin², Misran $^{1}$ \\
\hline & $\begin{array}{l}\text { ( }{ }^{1} \text { Department of Government Affairs and Administration, Universitas Muhammadiyah } \\
\text { Yogyakarta, Indonesia) } \\
\text { (' Jusuf Kalla School of Government, Universitas Muhammadiyah Yogyakarta, Indonesia) }\end{array}$ \\
\hline \multirow{3}{*}{$164-183$} & $\begin{array}{l}\text { Policy Networks: Actors, Interests, and Power Relations in the Jakarta } \\
\text { Reclamation Project }\end{array}$ \\
\hline & Rizki Hegia Sampurna1,2, Chih-Chieh Chou ${ }^{1}$ \\
\hline & $\begin{array}{l}\text { (' Department of Political Science, National Cheng Kung University (NCKU), Taiwan) } \\
\text { ( }{ }^{2} \text { Department of Public Administration, Universitas Muhammadiyah Sukabumi (UMMI), } \\
\text { Indonesia) }\end{array}$ \\
\hline \multirow{3}{*}{$184-197$} & $\begin{array}{l}\text { National Insights and Youth Political Attitudes in Rural Lampung Against } \\
\text { Negative Campaign }\end{array}$ \\
\hline & Hertanto $^{1}$, Handi Mulyaningsih², Asep Nurjaman ${ }^{3}$ \\
\hline & $\begin{array}{l}\left({ }^{1} \text { Departement of Government Science, Universitas Lampung, Indonesia) }\right. \\
\left({ }^{2} \text { Departement of Sociology, Universitas Lampung, Indonesia) }\right. \\
\left({ }^{3} \text { Departement of Government Science, Universitas Muhammadiyah Malang, Indonesia) }\right.\end{array}$ \\
\hline \multirow{3}{*}{$198-213$} & $\begin{array}{l}\text { Ethnic Identity and Local Politics: Study on Regional Head Election in } \\
\text { Merauke Regency } 2020\end{array}$ \\
\hline & Misran$^{1}$, Wahdania Sardi ${ }^{1}, Z^{2}$ uly Qodir ${ }^{1}$ \\
\hline & $\begin{array}{l}\left({ }^{1} \text { Department of Government Affairs and Administration, Jusuf Kalla School of Government, }\right. \\
\text { Universitas Muhammadiyah Yogyakarta, Indonesia) }\end{array}$ \\
\hline \multirow{3}{*}{$214-236$} & $\begin{array}{l}\text { Stakeholder Collaboration Model for Ecotourism Development: A Case } \\
\text { Study from Batu City, East Java Province }\end{array}$ \\
\hline & $\begin{array}{l}\text { I Gede Eko Putra Sri Sentanu' }{ }^{1} \text {, Ardian Prabowo', Klara Kumalasari'1, } \\
\text { Aulia Puspaning Galih', Rendra Eko Wismanu }{ }^{1}\end{array}$ \\
\hline & (' Departement of Public Administration, Universitas Brawijaya, Indonesia) \\
\hline
\end{tabular}


Farmers Social Movement Studies: A Systematic Literature Review for A Conceptual Model

$237-262 \quad$ Wahyudi $^{1}$

(' Department of Sociology, Universitas Muhammadiyah Malang, Indonesia)

Factors Affecting Trust in E-Government

Ulung Pribadi' ${ }^{1}$, Muhammad Iqbal ${ }^{2}$, Fittia Restiane ${ }^{3}$

263 - 276 (1 Post-Graduate Program Universitas Muhammadiyah Yogyakarta, Indonesia)

( ${ }^{2}$ Department of Political Science National Cheng Kung University, Taiwan)

$\left({ }^{3}\right.$ Department of Government Affairs and Administration Universitas Muhammadiyah Yogyakarta, Indonesia) 


\title{
Farmers Social Movement Studies: A Systematic Literature Review for A Conceptual Model
}

\author{
Wahyudi $^{*}$ \\ ${ }^{1}$ Department of Sociology, Universitas Muhammadiyah Malang, Indonesia \\ *Email Correspondence: wahyudiwinarjo64@umm.ac.id
}

\begin{abstract}
This research aims to formulate a conceptual model of farmers' social movement based on previous studies, which failed to explain this concept. The Systematic Literature Review (SLR) method with a mixture of qualitative and quantitative approaches was used to conduct this research. Data were obtained from 289 articles sourced from the Scopus Database, with the VOSVIEWER and NVIVO 12 software used to determine the conceptual model. The analysis results showed that this study is associated with farmers' issues, agricultural governance, agricultural systems, and the collaboration of stakeholders in managing agricultural production. These perspectives are used to explain the concepts, topics, and issues of the farmer's social movement, including the role of actors, dynamics of conflict, challenges, and struggles of the movement, processes, conservation, sustainable environment, cooperation, the collaboration of stakeholders, as well as production and marketing of agricultural products. This conceptual model contributes to the development of farmers' social movement studies oriented towards concept development and disclosing issues in the field.
\end{abstract}

Keywords: Farmers social movement, agricultural governance, environmentally sustainable, agroecology, government, farmers

\begin{abstract}
ABSTRAK
Paper ini bertujuan untuk memformulasikan konseptual model studi gerakan sosial petani berdasarkan pada penelitian terdahulu. Metode yang digunakan pada penelitian ini adalah metode Systematic Literature Review (SLR) dengan pendekatan campuran kualitatif dan kuantitatif. Pendekatan SLR digunakan untuk mereview 289 artikel yang bersumber dari Scopus Database.Review paper menggunakan software VOSVIEWER dan NVIVO 12 yang menghasilkan data untuk menjawab pertanyaan penelitian, yaitu bagaimana model konseptual studi gerakan sosial petani.Hasil analisis dengan SLR mengungkapkan bahwa studi gerakan sosial petani berkaitan dengan isu-isu gerakan petani, tata kelola pertanian, sistem pertanian, dan kolaborasi stakeholders dalam mengelola produksi pertanian, yang dijelaskan melalui perspektif sosiologi, ilmu lingkungan, dan manajemen pertanian. Perspektif tersebut digunakan untuk menjelaskan konsep, topik, dan isu-isu gerakan sosial petani, meliputi peran aktor, dinamika konflik, tantangan dan perjuangan gerakan, proses gerakan, konservasi, lingkungan berkelanjutan, kerjasama, kolaborasi stakeholders, dan produksi serta pemasaran hasil pertanian. Model konseptual tersebut berkontribusi terhadap pengembangan studi gerakan sosial petani, baik berorientasi pada pengembangan konsep maupun pengungkapan isu-isu gerakan sosial petani yang berlangsung di lapangan.
\end{abstract}

Kata Kunci: Gerakan sosial petani, tata kelola pertanian, lingkungan berkelanjutan, agroecology, stakeholders, government, farmers

Citation: Wahyudi. (2021). Farmers Social Movement Studies: A Systematic Literature Review for A Conceptual Model. Journal of Government and Civil Society, 5(2), 237-262. https:/ / doi.org/10.31000/ jgcs.v5i2.4961 


\section{INTRODUCTION}

The study of farmers' social movement discusses farmers' response, reaction, and resistance to the state and the private sector (Lindberg, 1994; De Weerd and Klandermans, 1999). Generally, this study focuses on farmers' efforts-to fight for their land rights, equality and justice for agricultural production, prices of commodities, and welfare. This is also associated with the democratization of agricultural affairs management, as making and determining seeds, access to information and policies, involvement in policy formulation, and farmers' autonomy and freedom(Levien, 2013). Mooney (2004) stated that the study of farmers' social movements also focused on formulating concepts, strategies, goals, and farming networks. The focus of the study on farmers' social movements is sociological issues, explained from the perspective of social, power, and capital theories sourced from sociology (Lindberg, 1994).

According to preliminary studies, farmers' social movement is related to resistance, conflict, land rights, power networks, and agricultural capitalism. Rather it is also associated with conservation, sustainable agricultural governance, and collaborative management in agricultural-related affairs (Leite, Silva, and van Ittersum, 2014; Freedman et al., 2016; Tripp, 2018; Futenma, De Castro, and Brondizio, 2020). The study's development and focus on farmers' social movement are not only explained from the perspective of social theories oriented to the disclosure of conflicts, problems of injustice, farmers' rights, and other sociological issues. Instead, it is also analyzed from a theoretical perspective and governance theory-oriented to developing, strengthening, and improving agricultural governance based on stakeholder collaboration, sustainable environment, and eco-friendly agricultural ecology(Wegren, 1996; Herring, 2015). Also, the study on farmer's social movement covers various disciplines and experiences a shift in orientation based on sociological, social, and governance theories (Futemma, De Castro, and Brondizio, 2020).

Although the farmer's social movement study has expanded the focus and orientation, no research has been carried out to scientifically explain related concepts and issues (Hiller, 1975; Pai, 2000). Previous studies were carried out partially, with the research implementation based on different perspectives and disciplines. Therefore, this research only can reveal one main problem, which is in line with the perspective and disciplines utilized by Dhanagare (2013). This research contributes to the formulation of a conceptual model for developing farmers' social movement studies, such as concept developmentoriented and those geared towards disclosing problems in the agricultural sector.

The review of articles in this study was not carried out based on a theory or concept of the peasant social movement, which limits the conceptual formulation of the model to concepts related to the theory used so that the conceptual model formulated does not describe the concepts and research topics of peasant social movements clearly. Therefore, 
the conceptual formulation of the model for the study of farmer social movements was carried out using a systematic literature review approach that focused on content analysis, bibliometrics, thematics, and topic networks in the study of farmer social movements. The conceptual formulation of this research model is based on theoretically, conceptually, and practically oriented previous studies associated with the problems of the agricultural sector in the field. This ensures that the conceptual model of this study clearly describes the concepts, topics, and related issues.

This research is to produce a conceptual model as a conceptual framework in developing a study of peasant social movements. The conceptual model formulated in this study can also be used as discussion material for scholars and practitioners to impact the development of concepts and theories for studying peasant social movements. The conceptual model impacts the exploration of problems in the agricultural sector in a comprehensive manner (Ajates, 2020). In addition, this concept is a roadmap, which provides a clear picture of the development, direction, and orientation that is integrated with several problems and visions of environmentally sound agricultural governance, ecosystems, ecology, agroecology, and environmental conservation to ensure the sustainability of the agricultural sector (Leite, Silva, and van Ittersum, 2014).

\section{LITERATURE REVIEW RELATED TO FAMERS' SOCIAL MOVEMENT}

The research on the farmers 'social movement is part of the objective of sociological studies that discusses the movement of this group is fighting for their interests and demands. This is related to equality, human rights, and justice for the state and against other dominant groups such as capitalists in agriculture (Levien, 2013; Falnikar and Dutta, 2019). Several sociological studies have focused on the issue of the peasant movement against the state that ignores farmers' rights such as land use, access to information, fairness in price policies, protection from global trade threats, and fair distribution of agricultural land(DeCelles, Sonenshein and King, 2020). Another focus of this study is their 'resistance to the domination and hegemony of global capitalist groups in agricultural affairs, such as the dominance of the trade-in drugs, environmental damage due to business interests, and neglect of farmers' rights in acquiring the opportunity to develop wisdombased agricultural products locally(Navajas-Romero, Del Río, and Ceular-Villamandos, 2020). Several focus studies on the issue of social movements are an inseparable part of the objectives of sociological studies related to both concept development and theoretically and practically oriented studies.

The study of farmers' social movements is related to sociological issues such as farmers' resistance, the relationship between state and private sector domination of farmers, and the struggle for justice for farmers. It is also associated with economic, ecological, and conservation issues. According to Gonçalves et al. (2013), Mutter et al. (1999), and Wegren 
(1996), economic issues are related to studies that focus on building networks and agricultural management to realize the welfare and prosperity of agricultural communities. In this context, several studies showed that the welfare and prosperity of farmers are influenced by the networks and institutions of the farming community(Falnikar and Dutta, 2019). Furthermore, studies revealed that these networks Significantly impact changes and improvements in people's lives. This also affects the sustainability of the agricultural sector as a contributor to national food security for a country(Amory Starr, 2010).

Several other studies have focused on farmers' social movements on ecological issues related to the efforts of farming communities to cultivate agricultural seeds oriented to a sustainable environment (Gordon, 1999). In this movement, farmers are faced with national and global capitalist groups that try to thwart society. Several studies revealed that agricultural capitalist groups, especially those engaged in cultivation, always want to dominate and master cultivation, from the manufacturing to the utilization and production stages(Herring, 2007; Tomlinson, 2008). The mission of the capitalist group is to direct and control farmers for business interests(Chappell et al., 2013). On the other hand, with the help of non-government organizations (NGOs), The farming community is trying to cultivate agricultural seeds that provide benefit and maintain the ecosystem(Herring, 2007; Levien, 2013). This group always fails to carry out their activities amicably in an ecological context because the capitalist is a strong actor supported by the State's power (Herring, 2007).

Farmers 'social movements on conservation issues are related to their efforts to maintain balance and environmental sustainability while using the environment as a productive area (Chappell et al., 2013; Makita, 2016; Patnaik, Jongerden, and Ruivenkamp, 2018). Conservation issues are initiated by environmental activists, academics, and local farmers(Dubois, 2008; Wright and Reid, 2011). The group seeks to understand the government and farmers on environmentally-oriented agricultural land management(Prentice, Chen, and Wang, 2019). Several studies revealed that environmental conservation issues are oriented towards maintaining the sustainability of the natural environment, which supports the survival of agricultural products (Dubois, 2008). The movement includes maintaining agricultural ecosystems, springs, consistency of rainfall, soil fertility, and avoiding environmental pollution from plantation activities that use chemicals. The success of this group in conservation issues is significantly dependent on the strength of the network and the cooperation of stakeholders, especially the involvement of environmental activists and university academicians (Gordon, 1999; Cadieux and Slocum, 2015).

This study has a special character that distinguishes it from others despite focusing on sociological, political, and environmental conservation issues (Dhanagare, 2014). Furthermore, other social movements such as political, bureaucratic reform, and moral movements are oriented towards collective efforts initiated by certain elites to change 
society's power structure, bureaucracy, and socio-cultural structure. Meanwhile, the farmers' social movement is a collective effort of a group of farmers that started with rights, access, and sustainability of agricultural ecosystems(Hasan, 1994; Mooney, 2004). In general, it was initiated by farmers that were dealing with some problems, such as land rights, eviction of agricultural land, unfair product prices, domination of the role of the state and the private sector in agricultural affairs, environmental damage due to mining exploration, and several other problems, which invited peasants to initiate social movements(Hinrichs and Allen, 2008; Tripp, 2018). Preliminary studies showed that the special characteristics associated with this movement illustrate a pure fighting process for their survival as farmers(Albrecht, 1972; A Starr, 2010).

Although previous studies have discussed farmers, the majority have mostly explained and disclosed movements, such as eviction from agricultural land, injustice in state policies, discrimination, unfair prices for agricultural products, and environmental conservation (T Brass, 1994; Carley, 2016). This preliminary study used an empirical approach with case studies in the field, namely a research process that records, observes, and provides in-depth discussions on cases associated with the studied farmer. In addition, there are also previous studies carried out with an experimental approach, which examines the success and failure factors by analyzing a case. Furthermore, several preliminary studies have revealed the various characteristics, model, strength, and network(Pai, 2000; J G Dal Belo Leite et al., 2015; Chen et al., 2019). According to Carley (2016), Hiller (1975), and Pai (2000), the theoretical approaches used to analyze these movements in previous studies are social, political, and economic theories. Therefore, the research represents findings that describe a particular field of science used as a perspective for the study.(Hiller, 1975; Pai, 2000; Carley, 2016)(Hiller, 1975; Pai, 2000; Carley, 2016)(Hiller, 1975; Pai, 2000; Carley, 2016)(Hiller, 1975; Pai, 2000; Carley, 2016)(Hiller, 1975; Pai, 2000; Carley, 2016)(Hiller, 1975; Pai, 2000; Carley, 2016)

This study led to the use of development and practice-oriented frameworks in various agricultural issues, which were not conceptualized in previous studies. Therefore, the conceptualization of this research needs to be carried out through a literature review approach, which focuses on mapping the formulation of concepts based on the linkage of agricultural social movements. One of the preliminary studies that explained the theory and concept is based on cases of land grabbing by the state and the private sector in India (Levien, 2013).

\section{RESEARCH METHOD}

This study used the Systematic Literature Review (SLR) method with a mixture of qualitative and quantitative approaches to conducting this research to analyze the data obtained from 289 articles on farmers' social movements sourced from the Scopus database 
(Khoo-Lattimore, Mura and Yung, 2019). A qualitative approach is used to layout topics and themes and conceptualize the concept based on previous studies(Dixon-Woods et al., 2006). Meanwhile, a quantitative approach is used to strengthen the concept focused on measuring the level of linkage between topics, sub-topics, issues, and study objectives (Sengers, Wieczorek, and Raven, 2019). The linkage was measured using correlation, coherence, and coherence tests with the Jaccard Index, similar to the concepts, subconcepts, topics, sub-topics, and study issues (Nicolas et al., 2018). The use of a mixed approach in this study allows the concept to be well-formulated, describing farmers' structured and systematic social movement strategies (Khoo-Lattimore, Mura, and Yung, 2019).

This research consists of the article identification, selection, and content analysis stages carried out systematically and sequentially. Furthermore, the stages are interrelated and support the collection of articles used as a unit of analysis to produce in-depth research findings capable of answering the following research question: (1) How is the distribution and clustering concept of the study? (2) How is the relationship between the concepts? (3) What is the level of correlation and coherence of the concept? And (4) What is the concept of the study on farmers' social movement? The three stages of the research implementation are shown in Figure 1.

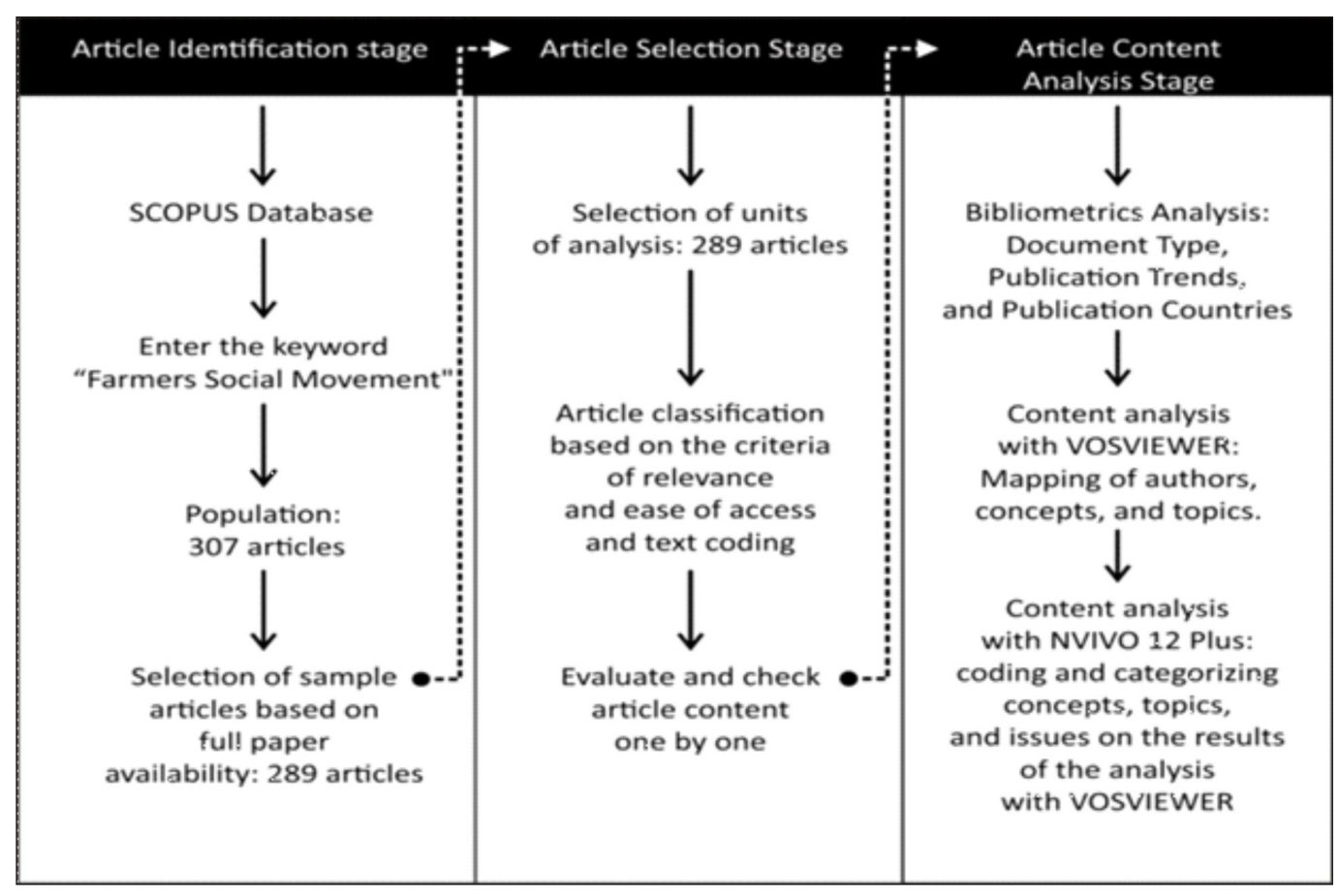

Figure 1. Research stages 
The first stage is article identification, which is related to article search activities by subscribing to Scopus, entering the keyword "Farmers Social Movement" in the document search column of the database, running the article search engine to produce the entire document as a whole, limiting the number of documents based on the type, source of articles (journal), and language used (English), as well as the implementation of "Limit to" article limitation menu. The second stage is the selection process, namely activities related to collecting articles used as a unit of review analysis which is carried out based on the relevance of the theme and title, the ease of access (open access), the readability of the text in the article content, and the types of files analyzed with content analysis software. The third stage is analyzing the article content using content analysis software, such as VOSVIEWER version 1.6. 16and NVivo 12 Plus version 2020. The purpose of using VOSVIEWER is to produce qualitative data on the concepts, topics, and issues associated with the study. The purpose of using NVivo 12 is to generate data on the relationship and coefficient of concepts, topics, and issues in the related study.

\section{FINDINGS DISCUSSION}

\section{Bibliometrics Analysis}

A total of 307 scientific publications consisting of 212 scientific journals, 36 books, 31 book chapters, 22 reviews, 4 editorials, and 4 conference papers were published in Scopus indexed publishers, as shown in Figure 2. This data shows that it is based on conceptual and field studies compared to publications in books, chapters, and reviews. The data also confirms that previous studies revealed more of the problems that occur in the field relating to agricultural governance and policies. Further problems are associated with the role of actors, conservation, and other problems in the agricultural sector, which are the object of this study.

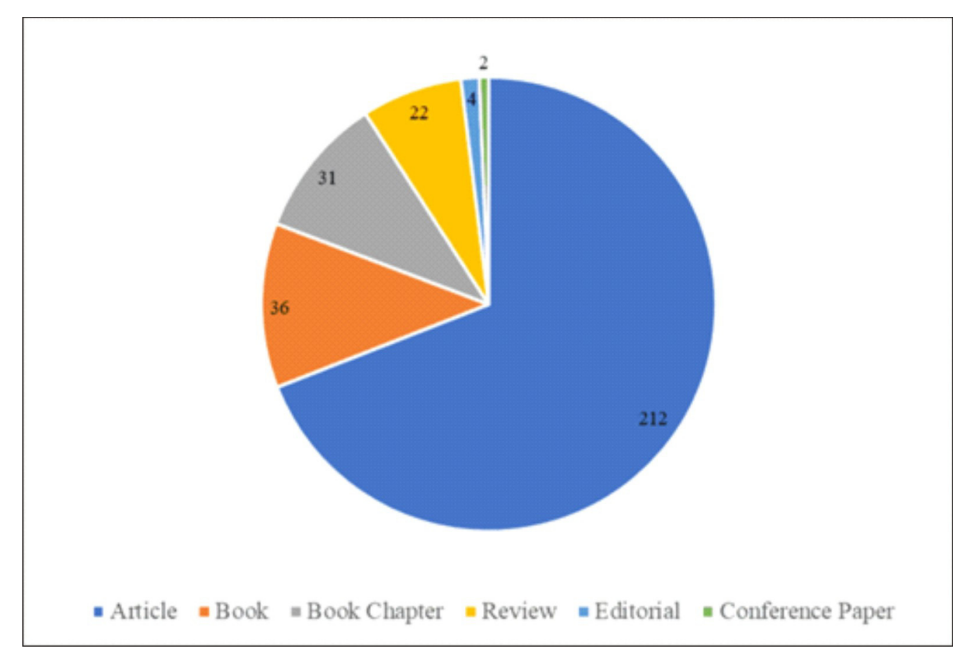

Figure 2. Documents by Type of Publication 
The gap in the number of publications between articles and other types of educational studies reveals that the research has not received serious attention from many scholars to compile references, both theoretically, conceptually, and practically. Another finding from these data is that conference studies are still not part of the tradition of authors and scholars, which shows that the dissemination of research results on issues or problems related to the social movement of farmers has not been widely conducted. Therefore, the latest research findings have not been widely utilized. Furthermore, this topic has not been disclosed and accessed by authors, scholars, and practitioners in agricultural sector governance.

Although there are gaps in the publication of articles, generally, this topic shows a positive trend, such as an increase in the yearly number of documents, which fluctuated, from 1-6, 10-15, 29, 17-19, 22, 12, 18 and 12 between 1971-2006, 2007-2009, 2010, 20112017, 2015, 2016, 2017-2019, and 2020, respectively as shown in Figure 3. The fluctuation in the number of published documents shows that this study has not received adequate attention from scholars, authors, and practitioners as a conceptual framework for developing scientific publications that discuss their various issues.

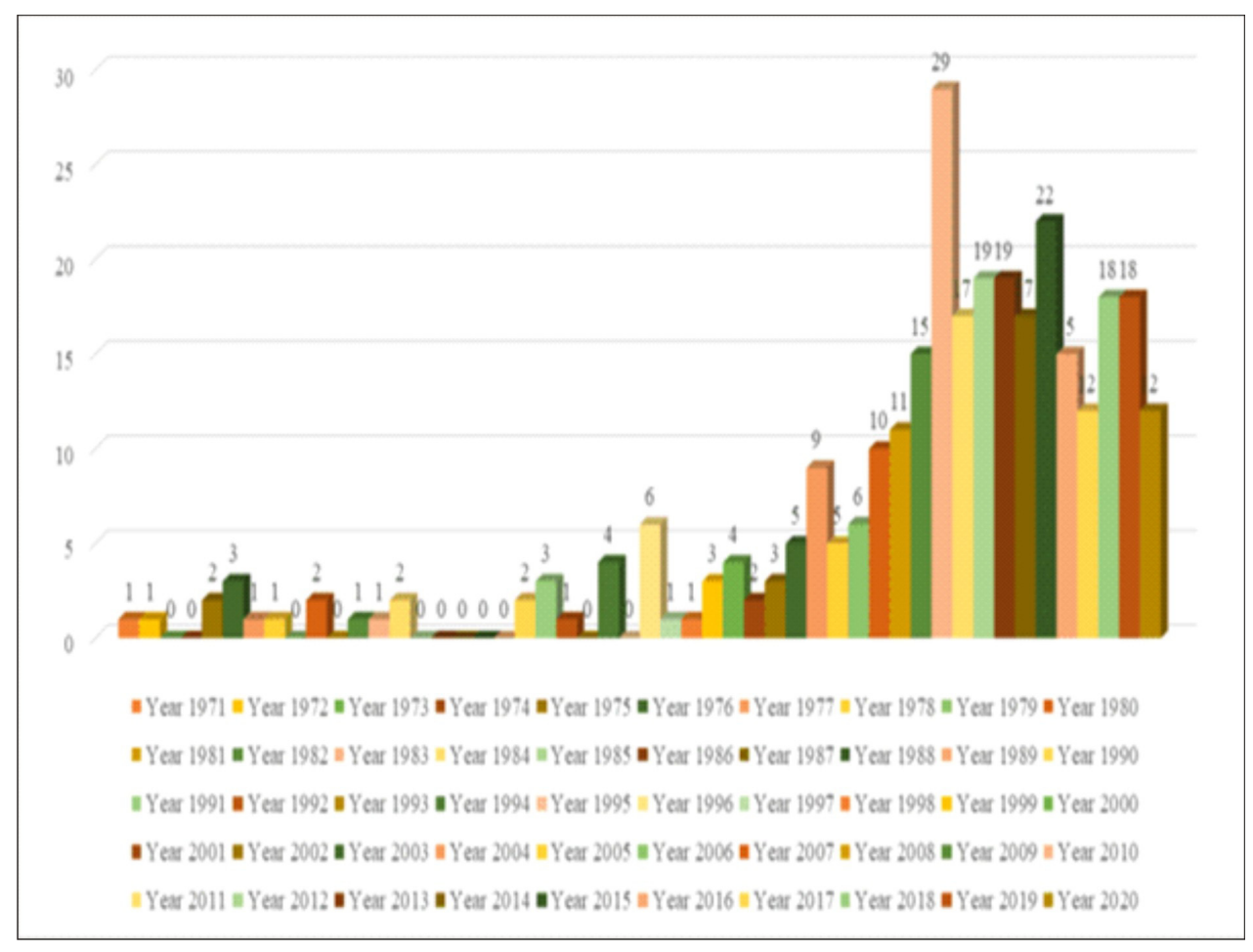

Figure 3. Publication Trends "Farmers Social Movement"

Developed countries, such as the United States (111 documents), the United Kingdom (34 documents), and Canada (24 documents), are concerned with the study of farmers' 
social movements. Other countries that have also paid important attention to problems in the agricultural sector are Brazil (16 documents), Netherlands (15 documents), India (13 documents), Italy (13 documents), Spain (13 documents), and Australia (13 documents), as shown in figure 3. These countries pay serious attention to research, publication, and dissemination of reports focused on agricultural issues related to governance, agroecology, conservation, sustainable environment, production, and sustainable ecosystems. India is one country that also focuses on farmers' rights, resistance, social movements, networks, land grabbing, and other sociological issues. The attentions of this country to these sociological issues are inseparable from the problems of its farmers, which are related to the state appropriation of farmers' land, injustice, and poverty. Sociological issues are also widely discussed and studied by other countries such as Sweden, China, Germany, Mexico, Ireland, Colombia, Czech Republic, France, Poland, Denmark, New Zealand, Norway, Switzerland, Austria, Finland, Indonesia, Israel, South Africa, Barbados, Belgium, Chile, Hungary, Kiribati, Malawi, Nigeria, Portugal, and Thailand.

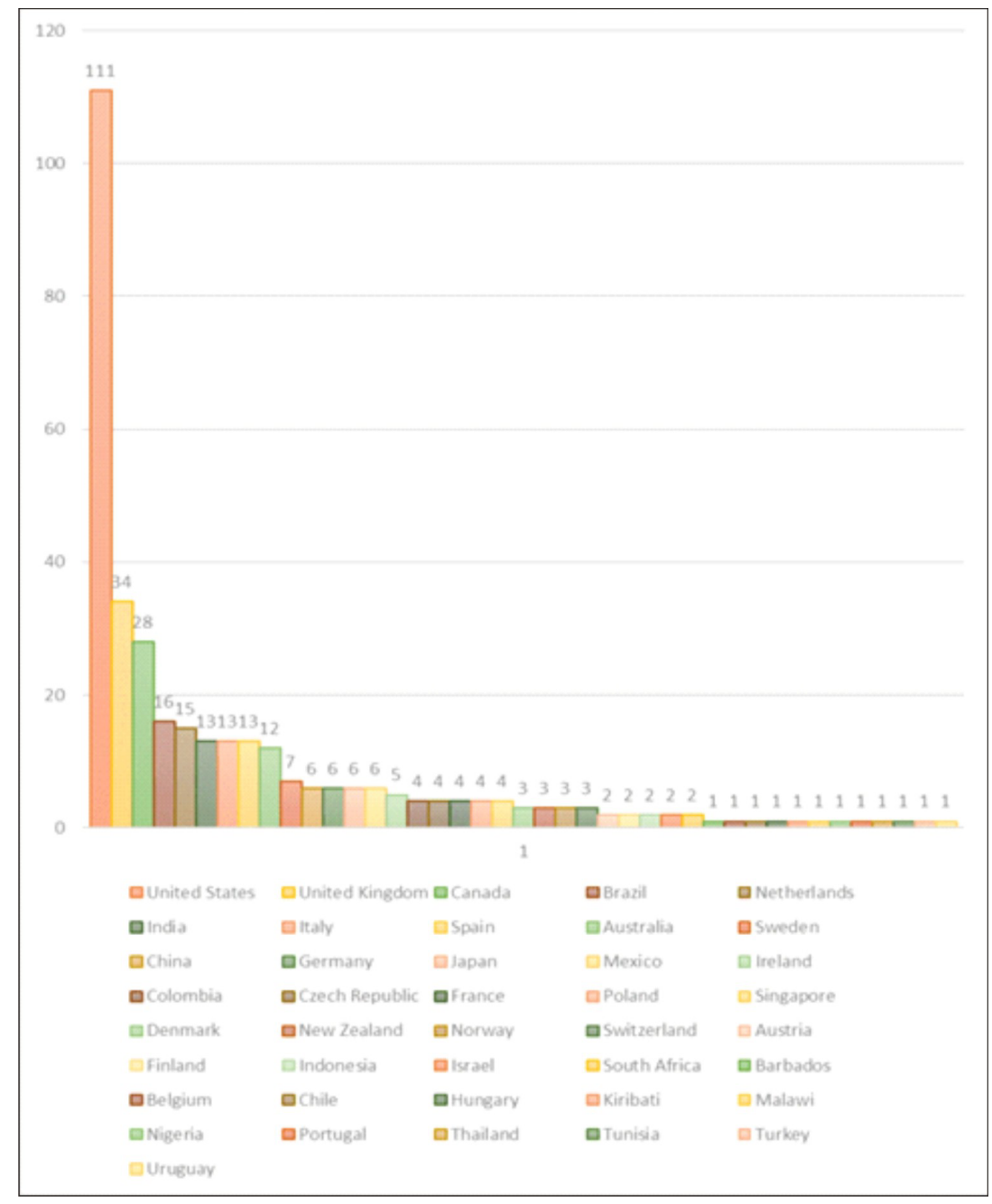

Figure 4. Publication "Farmers Social Movement" by Country 
Five clusters of scholars have contributed significantly to the production of scientific publications on this study. The first cluster comprises of Herring J.R, Svia V., Scones I., and Scoot J.C. The second is Mukherji R., Joshi, S., Gupta, D., Omvedt, G., Chatterjee, P., Escobar, A, and Marx, K. The third is Kneafsey, Moore, O, Allen, P, Guthman. J., Altieri, MA, Mcmichael, P, Miller, D, and Mooney, PH. The fourth is Harvey, D, Barnhurst, KG, and Neveu, E. And the fifth is Doylet, T, Smith, J, Malucci, A, Tilly, C, Rootes, C, Diani, M, Mcadam, D, Pinard, M, Snow, DA, Opp, KD, Sabucedo, JM, and Hunt, SA, as shown in Figure 4. The five clusters of writers are a collection of scholars and authors that play an active role in carrying out research activities and scientific publications on various farming-related issues. Furthermore, the five clusters have different objects of study and orientation tailored to the discipline and expertise of each author. Although there are differences in the object and orientation, each cluster has a relationship with one another.

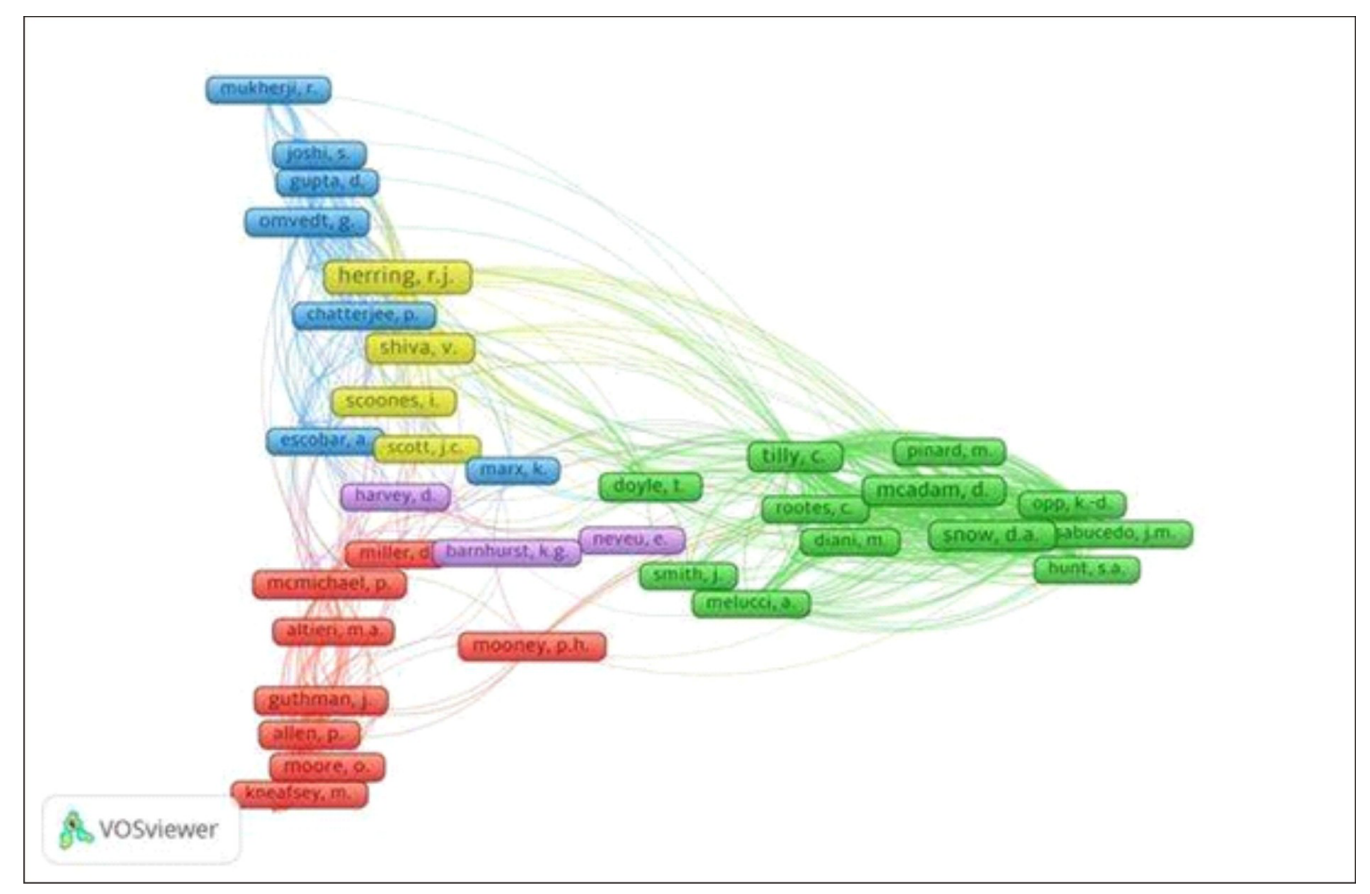

Figure 5. Authors' Co-citation Map

Figure 5 illustrates the network visualization of the author of the article on the Farmers Social Movement. The network describes the clustering of article writers who have the same research topic and theme. The first cluster indicates that this study focuses on farmers' socio-political movement, agricultural development and production, environmental conservation, economy, agriculture, and sustainable environment. Herring JR is the author with the most produced scientific publications on these issues. Herring JR's publications have been quoted by many other authors, including those from other clusters. The focus of the second cluster study is related to issues of socio-political movements, farmers' 
ideology, and resistance to the state. The focus of the third cluster study is related to the issue of agroecology, namely agricultural governance that is environmentally sustainable and based on collaboration, synergy, and a network of stakeholders in carrying out agricultural policy governance activities. The focus of the fourth cluster study is related to the concepts of the farmers' social movement, which includes strategies, forms, and models in fighting for their rights, aspirations, and demands from the state. The focus of the fifth cluster study is related to the process and dynamics of farmers.

\section{Dominant Concepts and Issues in the Study of Farmers Social Movement}

Based on the content analysis results of 289 studies using Vosviewer, the dominant concepts and issues in this study, which consist of the movement, governance, power, networks, processes, challenges and movement systems, development, actor relations, political influence, behavior, and collective awareness, movement effectiveness, the role of decision-makers, the impact of the movement, dynamics and conflicts, the role of actors, civil society, resistance and power, justice, conservation, initiatives and innovations, and activist movements, are shown in Figure 6. A number of these dominant concepts and issues have been the center of attention in previous studies, illustrating the study's objective related to agricultural governance. Furthermore, this involves many actors that communicate to build political networks and power in influencing decision-making processes that impact the agricultural sector, including conservation, agroecology, land use, forests, rural areas, and tourism development.

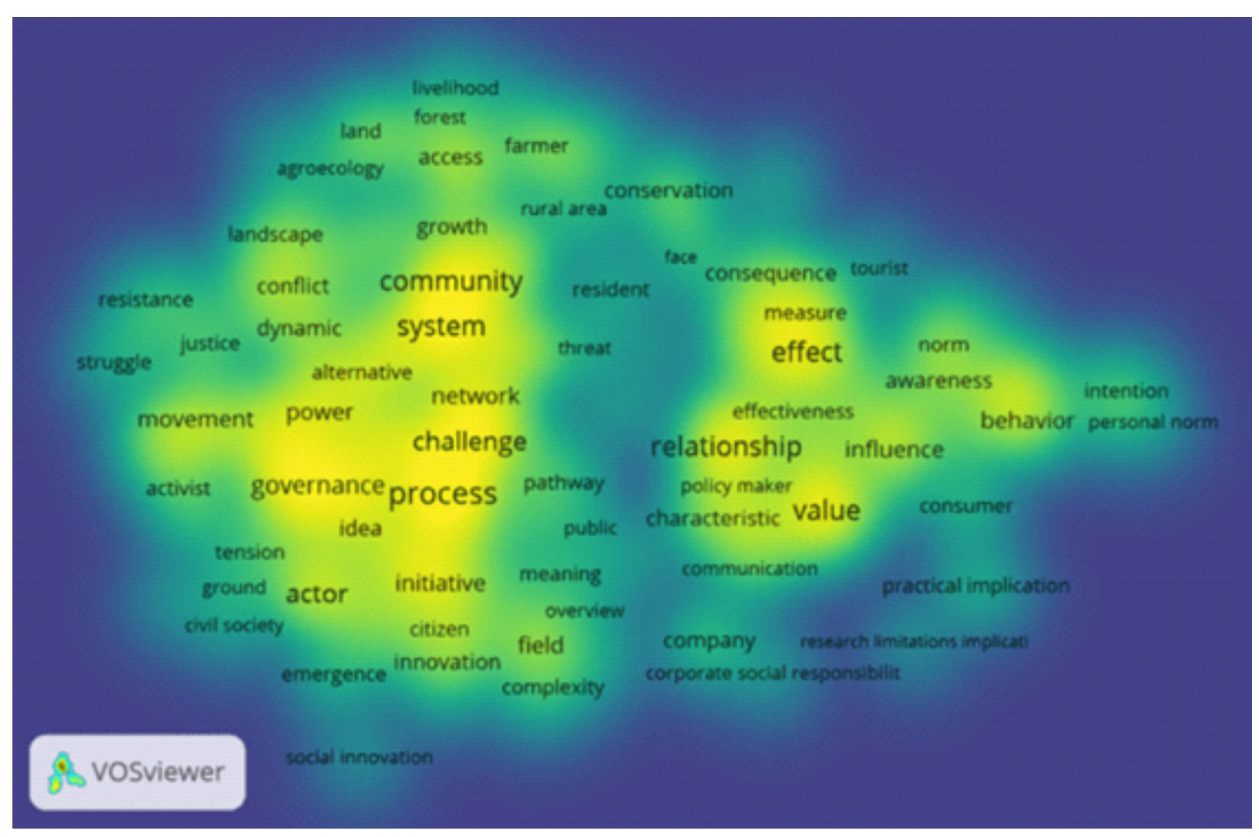

Figure 6. Cluster Density View of the Visualization of 283 Papers 
Based on the dominant concepts and issues previously mentioned, this study is related to political sociology, environmental, and agricultural sciences. Concepts and issues directly related to sociology include social movements, conflict dynamics, the role of actors, civil society movements, power, political networks and influence, resistance, justice, communication, actor relations, and challenges. A number of these concepts and issues are the object of study, which are part of the discipline of sociology widely used to explain farmers' community resistance to the state in various cases. Some of these cases include the state's expropriation of farmers' land, discriminating their rights to state policies, and the state's neglect of their needs and aspirations. In the context of environmental science, this study is related to the concepts and issues of conservation of agricultural areas, sustainable environment, conservation of protected areas, forestry, and environmental crisis management. This study's concepts and issues are also related to agricultural science, namely biotechnology, agroecology, consumerism, rice fields, and rural areas. The linkage of this study with the discipline of agricultural science is a unified system that clearly shows that the object is directly related to agricultural problems in rural areas.

The characteristics of the dominant concepts and issues in this study-follow the disciplines of sociology, environmental and agricultural sciences, which illustrate that the concepts and issues discussed are a unity of farmer problems. Environmental issues and agricultural affairs are inseparable ecosystems. Characteristics of concepts and issues in the study of farmer social movements emphasize that it is directly related to the efforts of farmers to fight for rights, access, and justice which are expected to affect the responsiveness of the state and the private sector in formulating policies and regulations that are in favor of the interests of farmers for sustainable environment, and agricultural ecosystems. The formulation of the dominant concepts and issues in the study of the farmer's social movement is distributed into three clusters: the social movement and governance, the community and agricultural system, and the stakeholder relationship and agricultural products, as shown inTable 1. 
Table 1. Clusterization of the Study Concept of Farmers' Social Movement

\begin{tabular}{llc}
\hline \multicolumn{1}{c}{ Cluster } & \multicolumn{1}{c}{ Concepts } & Total \\
\hline $\begin{array}{l}\text { Red Color: } \\
\text { Movement and } \\
\text { Governance }\end{array}$ & $\begin{array}{l}\text { Movement, governance, process, challenge, project, } \\
\text { power, network, plan, initiative, actor, citizen, } \\
\text { diversity, field, complexity, emergence, civil society, } \\
\text { recognition, justice, struggle, resistance, conflict, }\end{array}$ & \\
& dynamic, public, growth, activist, bottom. & \\
Blue & System, community, rural area, landscape, & 12 \\
Color:Agriculture & agroecology, land, access, forest, livelihood, farmer, & \\
System & conservation, capacity. \\
Green Color: & $\begin{array}{l}\text { Relationship, product, affect, behavior, value, } \\
\text { Stakeholders }\end{array}$ & communication, company, comparison, influence, \\
Relationship & intention, personal norm, belief, driver, adaption, & \\
& consequence, participant, characteristic, promotion, & \\
& resident, face, tourist, household. & \\
\hline
\end{tabular}

Social movement and governance clusters (red color) are related to the concepts and topics of movement processes and challenges, agendas, networks, power, conflict dynamics, roles of actors and civil society, resistance, justice, initiatives, innovation, movement crises, and the diversity of actors. The cluster shows concepts and topics related to sociological issues, confirming that the sociology discipline plays an important role in this study. The study also confirms that sociology is the source of social movement concepts and theories widely used by authors to explain farmers' movement in various issues, including land grabbing, state discrimination, private sector domination, biotechnology issues, and protection of state policies against farmers. Community clusters and agricultural systems (blue color) are related to the concepts and topics of agroecology, agricultural land systems, forest area management, farmer access, conservation, and agricultural management in rural areas. The cluster of stakeholder relations (green color) and the value of agricultural products are related to the concepts and topics of agricultural impacts, consumer behavior, and awareness. It is also associated with the promotion, the role of agricultural companies, the attention and personal characteristics of the state, farmers and capital owners, CSR programs, and adaptation of agricultural technology. 


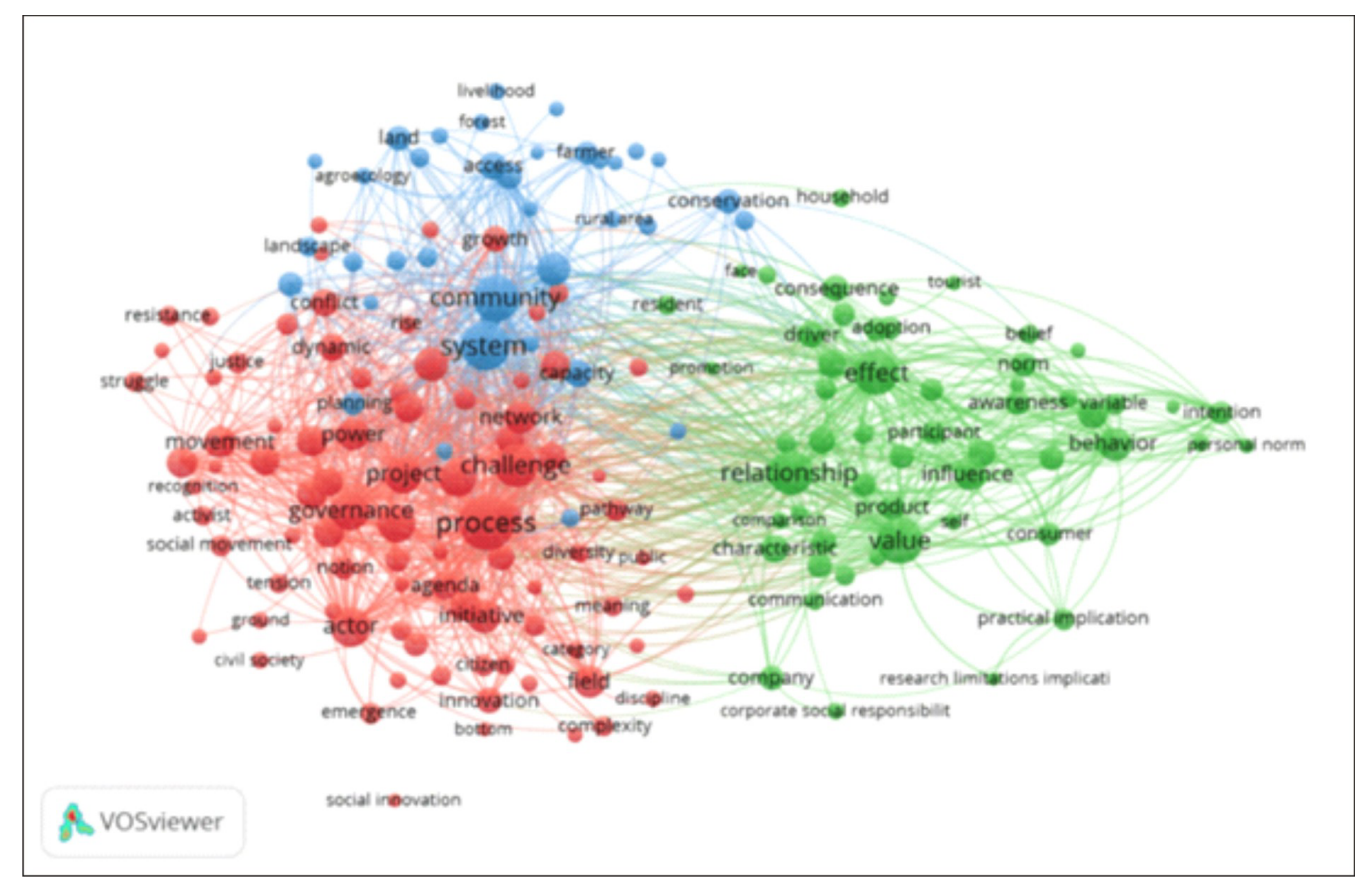

Figure 7. Network Visualization of Farmer Social Movement Studies

The three clusters of dominant concepts and topics mentioned above are an integrated unit of farmer social movements and governance that deals with the numerous concepts and topics in the same network. The NVivo 12 Plus analysis result showed that the concepts and topics of each cluster have strong linkages, co-efficiencies, and coherence with the Jaccard's value of 0.8-0.9. This indicates that the concept of this study is related to social movements. The agricultural system and stakeholder relations are also related to problems in the agricultural sector and the environment. 


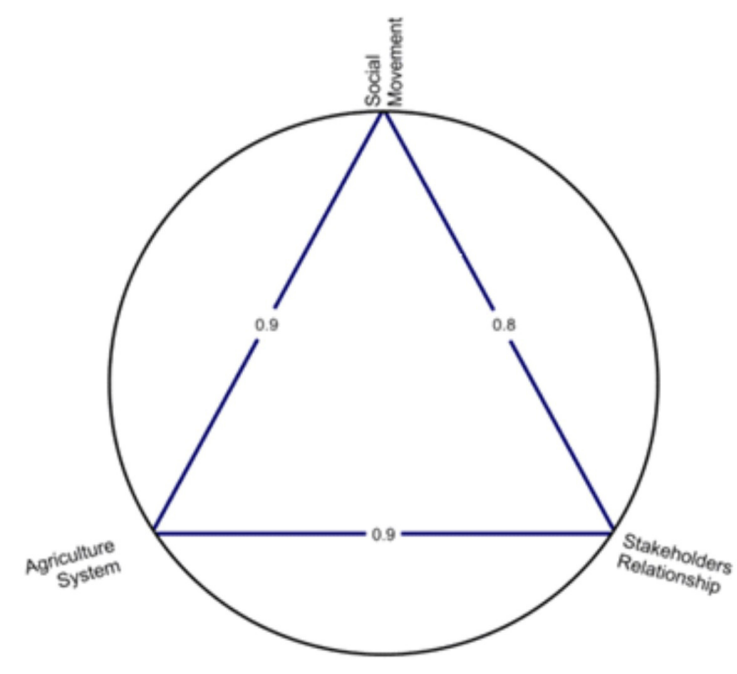

Figure 8. The Relationship between the Concepts in the Study "Farmers Social Movement"

Figure 8 shows the relationship between social movement clusters and governance, community clusters and agricultural systems, and clusters of stakeholder relations and the value of agricultural products. The three conceptual clusters and topics in this study have a strong relationship. It is a strategy that deals with agricultural-related systems, community roles, stakeholder relations, the value of agricultural products, and environmental issues. The strong relationship between the three concept clusters and the topic is the conceptual foundation in formulating the concept comprising sub-concepts and sub-topics.

\section{Conceptualization of the Study of Farmers' Social Movement}

The social movement and governance cluster is a concept that is directly related to power, actor networks, conflict, roles, farmers' community involvement, movement struggles, awareness, processes, challenges, and agricultural programs, as shown in Figure 9. The linkage of the concepts in the cluster shows a strong coherence with the Jaccard's score scale of $0.8-0.9$, which emphasizes that power in social movements and governance is a form of the state's role, which has the authority to determine the agricultural sector policies. In this case, the study is related to their efforts to influence and agree with the state in making policies that favor farmers' interests. An instance is the control and protection of land against the domination of capitalist groups in the agricultural sector. One of the farmers 'strategies is to build and strengthen political networks that involve many actors, including civil society organizations. This enables the collective ability of farmers' to collectively face the dynamics of conflicts, challenges, and through massive movement processes, capable of influencing the state policy. 


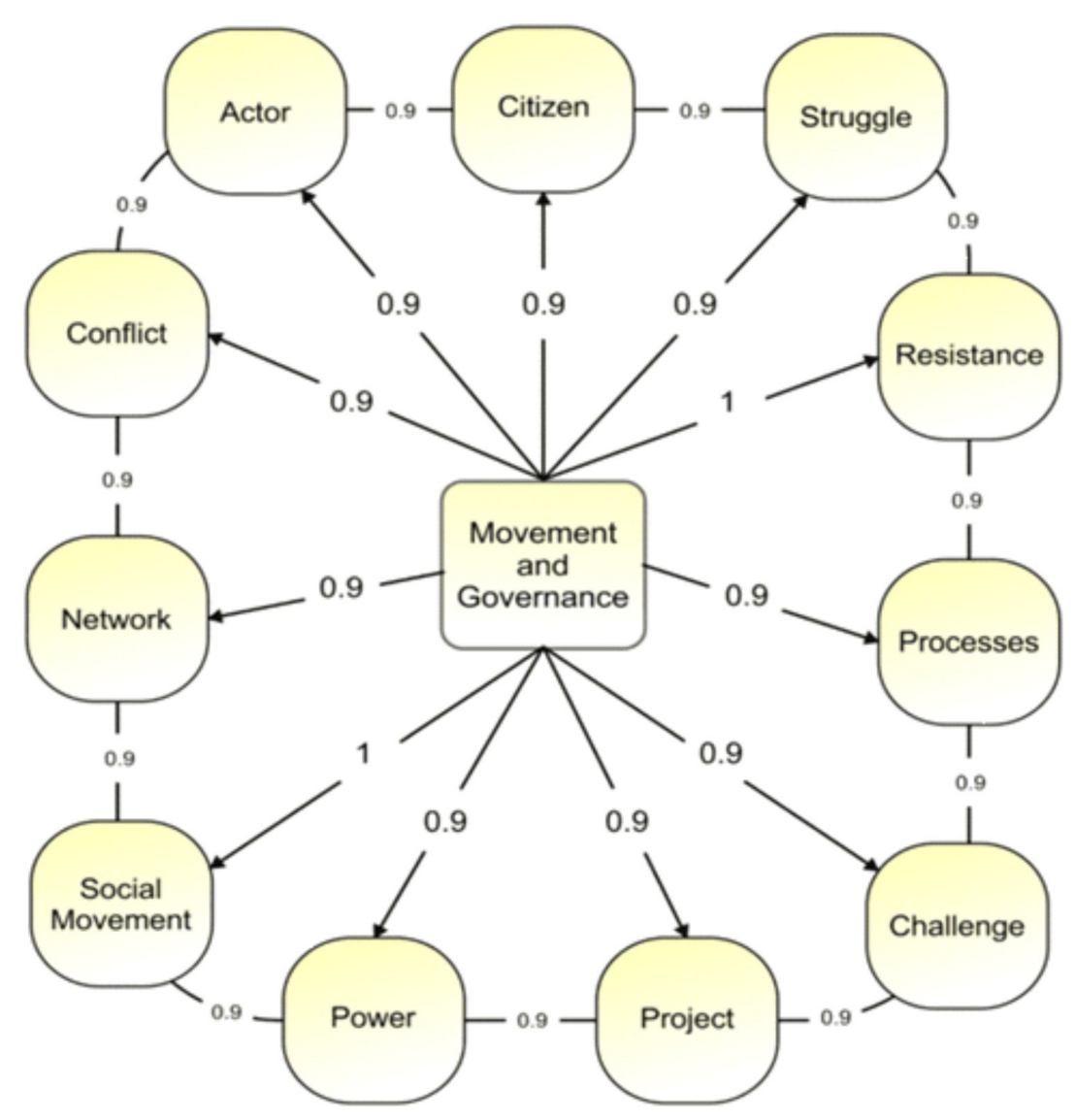

Figure 9. The Relationship between the Concepts and Sub-concepts of Movement and Governance in the Study of "Farmers Social Movement"

The value of the relationship and the coherence of the concept of social movements and governance in Figure 9 confirm that both describe farmers' activities. This is related to their efforts to influence agricultural governance policies through various forms of movement, such as resistance, building and strengthening networks, organizing and mobilizing actors, such as community groups and civil society organizations, facing various challenges and collective struggles. The farmers' social movement is faced with the state's power, which has the authority to formulate and determine policies and programs related to agricultural affairs. The formulation of farmers' social movement concept is related to many theories and concepts in sociological studies. This illustrates that the concept is related to resistance, conflict, struggle, and collective missions to fight over state resources and influence the direction of state policy to take sides.

The social movement cluster and agricultural system is a study concept of farmers that is strongly related to conservation issues, land use, agricultural ecology, the existence of farming communities, and access to agricultural resources, with a Jaccard value scale 
of $0.8-0.9$. This study on conservation issues are related to farmers' efforts to overcome environmental damage caused by the expansion of agricultural land, mining exploration, and the use of chemicals. Activists initiated the issue of conservation from civil society organizations and authors from various universities. They provide education and socialization of environmental conservation to farming communities to ensure farmers' awareness to build a collective strength to support conservation activities. The social movement of farmers in land use issues is related to their efforts to influence the state's power in distributing land use in favor of their interests. In this case, farmers are faced with the power of the state and capitalist groups. The state provides access to capitalist groups to control land use. Therefore, farmers are not suitable to access land for agricultural purposes.

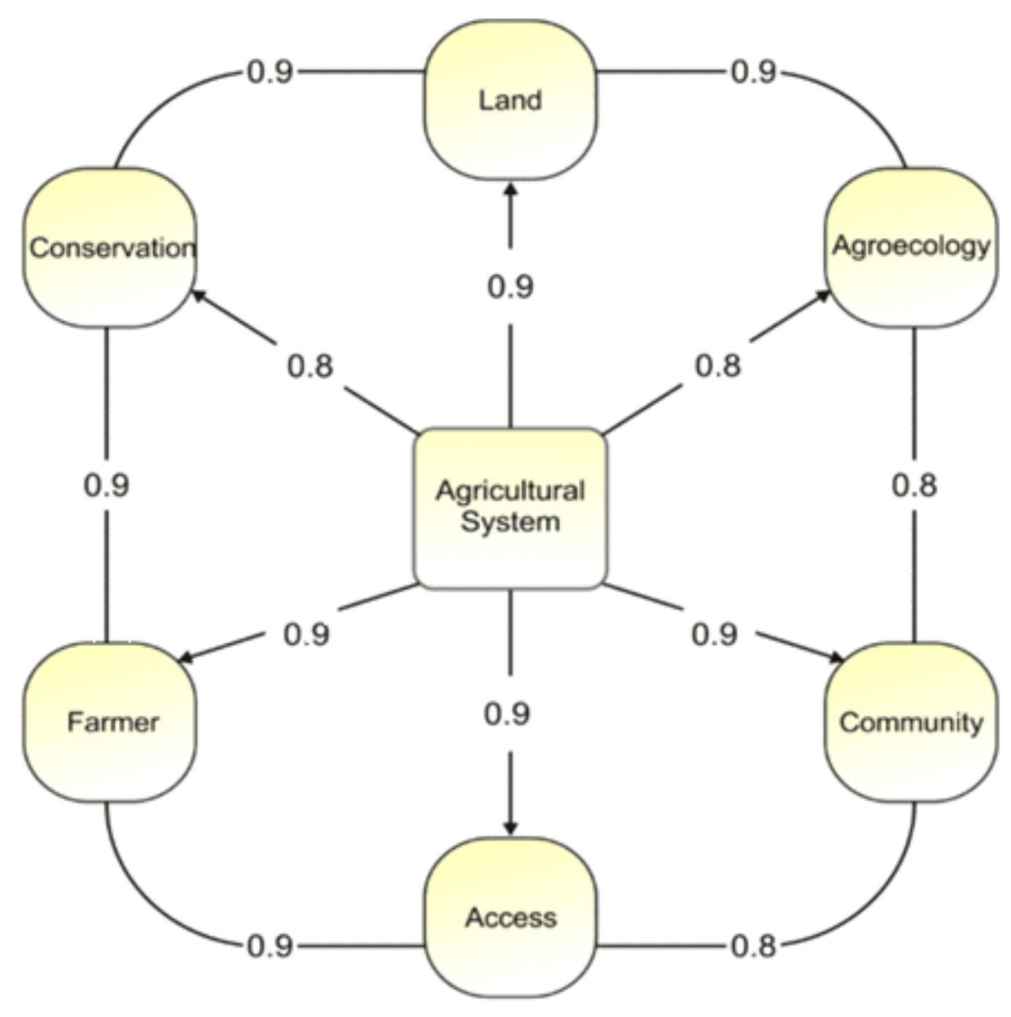

Figure 10. The Relationship between the Agriculture System Concept and its Subconcepts in the Study "Farmers Social Movement"

Farmers' social movement in the issue of agricultural ecology is related to their collective efforts to maintain the sustainability of the agricultural ecosystem by integrating management oriented towards a sustainable environment through an organic approach. In many studies, this movement is based on a participatory and collaborative approach from various stakeholders, such as the private sector, farmers, and the government, which 
jointly formulate programs and strategies to support agricultural land use for economic benefits and sustainability of its ecosystems. The agroecology-oriented movement involves community participation. There are access and opportunity for them to obtain information and education on conservation, agricultural governance, and land use, which is environmentally oriented sustainably.

The stakeholder relationship cluster in this study is related to the relationship between farmers, the private sector, and consumers of agricultural products. These concepts and sub-concepts have a very strong relationship with Jaccard's Scale Score of 0.8-0.9. In this context, farmers seek to build synergy with several mutually beneficial parties in agricultural production activities. However, several studies showed that the state and the private sector are the dominant actors in regulating agricultural production activities, marketing, and determining the price of products directed at the interests of the state and private sector. For instance, farmers are interested in maintaining the sustainability of the agricultural ecosystem. Furthermore, the state has an interest in increasing agricultural sector income by involving the private sector. However, several other studies showed that farmers and the private sector work together to manage the agricultural sector, which is mutually beneficial to the economy for stakeholders and maintains sustainability.

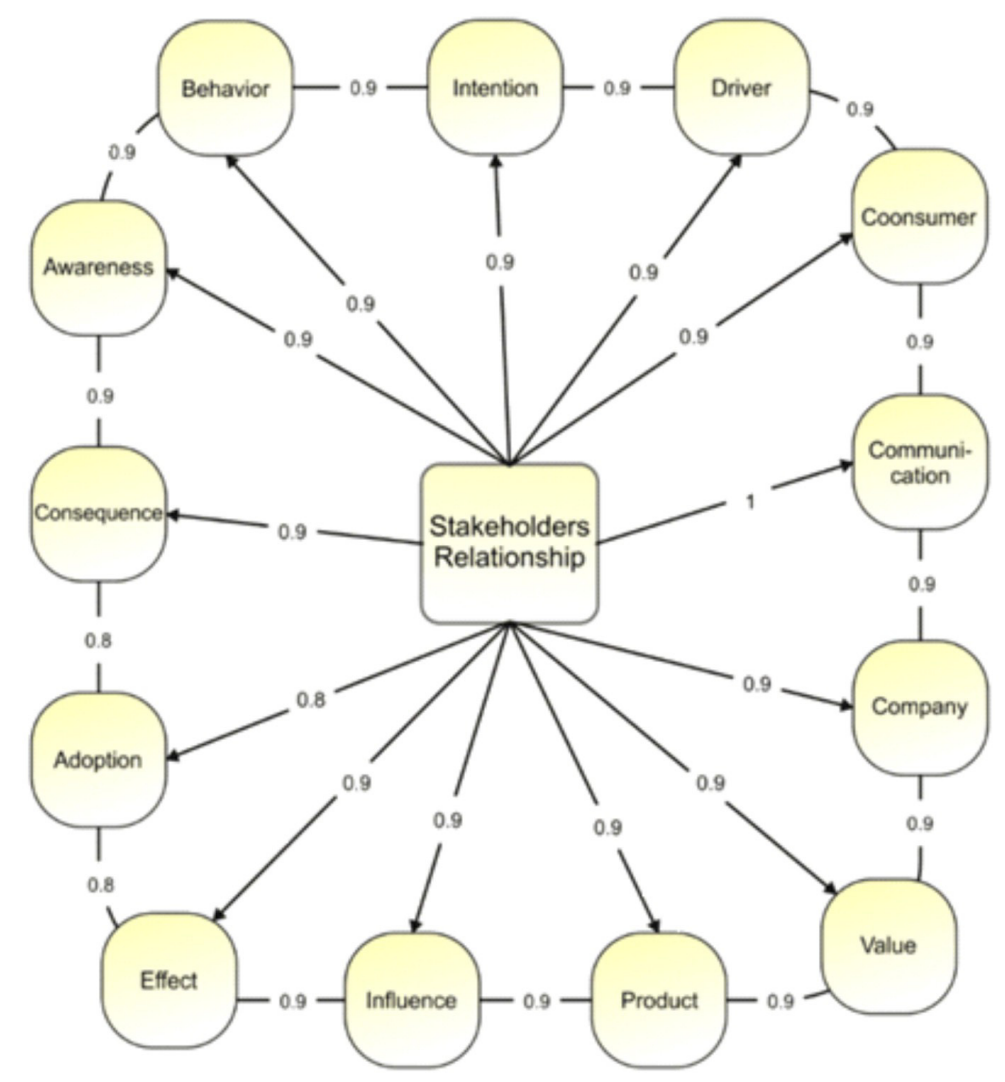

Figure 11. The Relationship between the Concept of Stakeholders and Sub-concepts in the Study "Farmers Social Movement" 
The synergy of stakeholders in managing the agricultural sector depends on the predetermined values, their influence, impact, adaptation to change, the consequences of the relationships formed, the awareness and behavior of each stakeholder in perceiving the agricultural sector. Previous research showed that stakeholders have different values. Therefore, it requires a communication process to equalize the process aimed at a sustainable agricultural ecosystem. The influence of stakeholders in the farmers' social movement is related to the ability of each stakeholder to influence other actors in forming networks that play a significant role in building awareness and shaping behavior with a sustainable environmental perspective. The relationship between stakeholders in the farmer social movement is particularly directed towards realizing a sustainable agricultural ecosystem between the economic interests of farmers, the private sector, the state, and the interests of a sustainable environment.

\section{Conceptual Model of Farmers' Social Movement Study}

Based on the concept mapping analysis, it was formulated that this study is related to three main concepts, namely social movements and governance, agricultural systems, and stakeholder relations. Furthermore, these three main concepts have their respective sub-concepts, which are related to one another. The concept of social movement and governance comprises sub-concepts with a sociological character, such as power, sociopolitical networks, conflict, resistance, struggle, civil society, actors, civil society, and social movement processes. The sub-concept in the concept shows that the study of farmers as part of sociological research related to theories of social movements, conflict, and class struggle, is used to explain and understand their problems. The orientation of the movement related to this concept is directed at the struggle and resistance of peasants against state policies that ignore the interests of farmers and prioritize the interests of global capitalist groups(Tom Brass, 1994).

Sub-concepts in the concept of agricultural systems are related to the community (farmer groups), land management, agroecology, management of protected areas (forests), conservation, and empowerment of the agricultural sector. This sub-concept is an integrated and interrelated concept that focuses on collective movements in realizing sustainable environmentally-oriented agricultural governance. The agricultural system describes a movement based on education, research, and socialization oriented towards building mutual awareness in realizing environmental balance, such as agricultural, conservation, and nature activities carried out through an agroecological approach(Ajates, 2020). As part of a collective movement, the social movement in this context involves many actors, including farmers, environmental activists, authors, the government, and the private sector(Prost et al., 2019). 
The sub-concept of stakeholder relations is related to cooperation, the role of the private sector, awareness, behavior, consumers, agricultural production, values, communication, and the influence and impact of stakeholder cooperation in managing agricultural affairs. This sub-concept is used to describe the cooperation of stakeholders, which is carried out through the communication process and the formation of the same awareness and vision (values) in supporting the achievement of the interests for environmental sustainability(Roy, Hall, and W. Ballantine, 2017). Therefore, it is in the state's interest to increase the agricultural sector's income through the involvement of the private sector that plays a role in the production and marketing of agricultural products. This process also emphasizes the balance of the natural and social environment of farmers (agricultural ecosystem). Apart from being profit-oriented, the private sector also emphasizes paying attention to social responsibility for the sustainability of farmers and the natural environment(João Guilherme Dal Belo Leite et al., 2015).

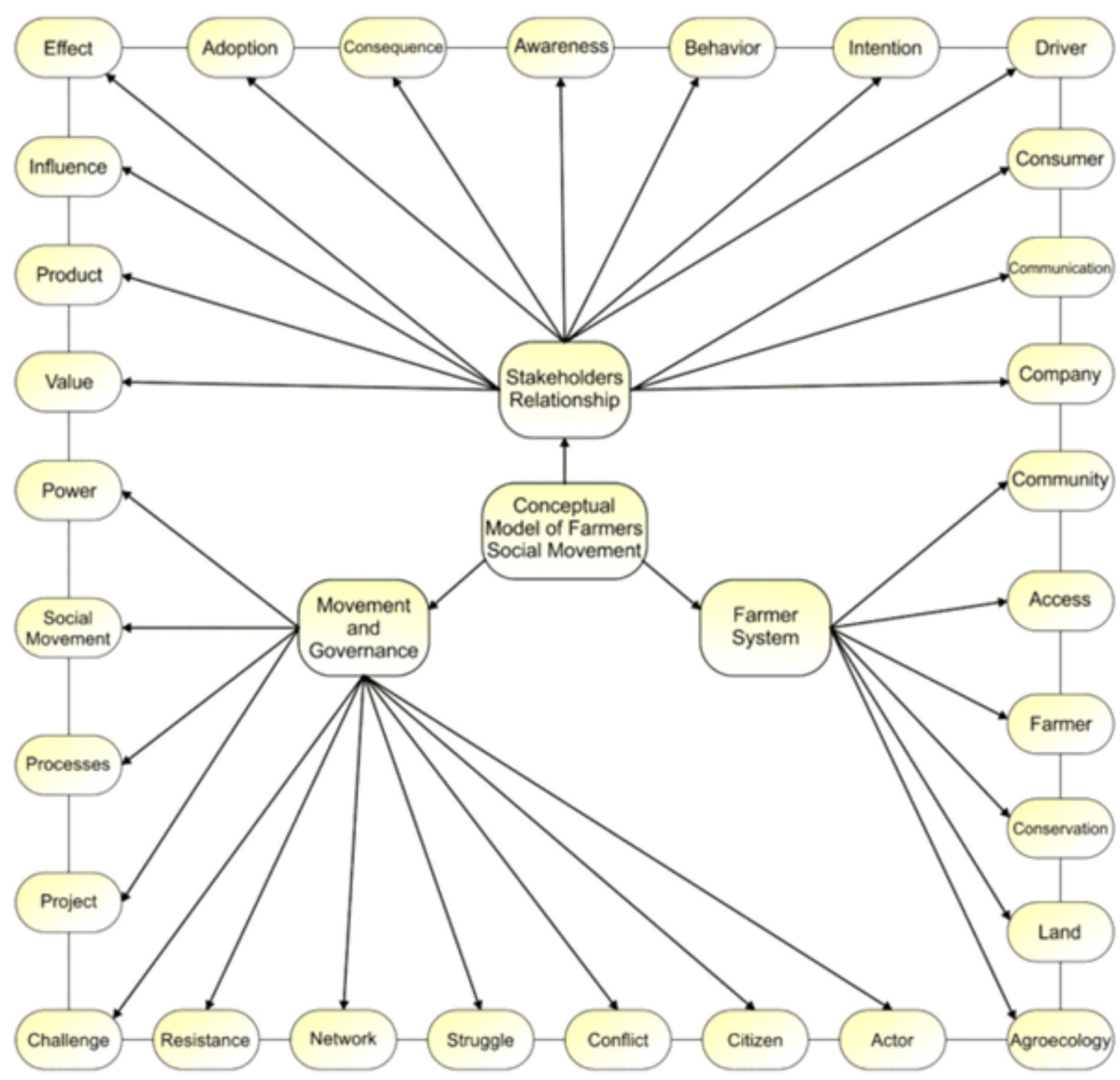

Figure 12. Conceptual Model of Farmers' Social Movement Study 
Figure 12 confirms that the three main concepts and their respective sub-concepts are unitary concepts related to one another in the study of farmer social movements. The concept formulation clearly illustrates that the study of peasant social movements is associated with sociological concepts related to resistance, resistance, conflict, actor movements, and movement networks, and rural concepts, namely agricultural governance conservation and agroecology. Besides, the study of farmers' social movements is also related to the concept of agricultural management, which is related to the cooperation of stakeholders in managing the agricultural sector, especially in the aspects of production and marketing of agricultural products.

\section{CONCLUSIONS}

This study formulates that the farmer's social movement is related to many sub-concepts originating from various disciplines, especially sociology, agricultural science, and management. The diversity of sub-concepts has various characters and orientations, oriented towards the struggle for farmers' rights and justice in the agricultural sector, land use, and protection of product prices. The concept of agricultural systems emphasizes the study of farmer movements focused on conservation activities and the balance of ecosystems oriented towards sustainability. The concept of stakeholder relations emphasizes cooperation in managing the agricultural sector, which is oriented towards achieving the interests of stakeholders that pay attention to the ecosystem's interests.

This study's concept is oriented towards justice in state policies, agroecology, conservation, sustainable environment, agricultural management networks, and sustainable agricultural ex-systems. The concept is used to explain various agricultural issues and problems. It allows the study to develop scientifically, to determine agricultural problems and agroecological orientation. However, this study has some limitations in terms of testing; for instance, the concept formulated is still based on previous studies. Therefore, subsequent studies need to focus on testing the concept of the farmer social movement study formulated in this research with field problems that describe the complexity of issues or problems in the agricultural sector.

\section{REFERENCES}

Ajates, R. (2020) 'An integrated conceptual framework for the study of agricultural cooperatives: from repolitisation to cooperative sustainability', Journal of Rural Studies. Duncan of Jordanstone School of Art and Design, University of Dundee, Dundee, United Kingdom: Elsevier Ltd, 78, pp. 467-479. doi: 10.1016/j.jrurstud.2020.06.019. Albrecht, S. L. (1972) 'Environmental Social Movements and Counter-Movements: An Overview and an Illustration', Nonprofit and Voluntary Sector Quarterly. Department 
of Sociology Utah State University, United States, 1(4), pp. 2-11. doi: 10.1177/ 089976407200100401.

Brass, T (1994) 'The Politics of Gender, Nature and Nation in the Discourse of the New Farmers' Movements', The Journal of Peasant Studies. Faculty of Social and Political Sciences, University of Cambridge, Free School Lane, Cambridge CB2 3RQ, United Kingdom, 21(3-4), pp. 27-71. doi: 10.1080/03066159408438554.

Brass, Tom (1994) The Politics of Gender, Nature and Nation in the Discourse of the New Farmers' Movements, The Journal of Peasant Studies. doi: 10.1080/03066159408438554.

Cadieux, K. V and Slocum, R. (2015) 'What does it mean to do food justice?', Journal of Political Ecology. Department of Sociology, University of Minnesota, Minneapolis, MN 55455, United States: University of Arizona Libraries, 22(1), pp. 1-26. doi: 10.2458/ v22i1.21076.

Carley, R. (2016) 'Ideological contention: Antonio gramsci and the connection between race and social movement mobilization in early twentieth-century Italy', Sociological Focus. Wright State University, United States: Taylor and Francis Inc., 49(1), pp. 2843. doi: 10.1080/00380237.2015.1065700.

Chappell, M. J. et al. (2013) 'Food sovereignty: An alternative paradigm for poverty reduction and biodiversity conservation in Latin America', F1000Research. Institute for Agriculture and Trade Policy, Minneapolis, MN 55404, United States: Faculty of 1000 Ltd, 2. doi: 10.12688/f1000research.2-235.v1.

Chen, L. A. et al. (2019) 'The foundations of institutional-based trust in farmers' markets', Agriculture and Human Values. College of Economics and Management, Nanjing Agricultural University, No. 1 Weigang Road, Nanjing, Jiangsu 210095, China: Springer Netherlands, 36(3), pp. 395-410. doi: 10.1007/s10460-019-09923-4.

Dal Belo Leite, J G et al. (2015) 'Socioeconomic and environmental assessment of biodiesel crops on family farming systems in Brazil', Agricultural Systems. Plant Production Systems, Wageningen University, P.O. Box 430, Wageningen, AK, 6700, Netherlands: Elsevier Ltd, 133, pp. 22-34. doi: 10.1016/j.agsy.2014.10.005.

Dal Belo Leite, João Guilherme et al. (2015) 'Socioeconomic and environmental assessment of biodiesel crops on family farming systems in Brazil', Agricultural Systems. Elsevier Ltd, 133(November), pp. 22-34. doi: 10.1016/j.agsy.2014.10.005.

DeCelles, K. A., Sonenshein, S. and King, B. G. (2020) 'Examining Anger's Immobilizing Effect on Institutional Insiders' Action Intentions in Social Movements', Administrative Science Quarterly. University of Toronto, Canada: SAGE Publications Ltd, 65(4), pp. 847-886. doi: 10.1177/0001839219879646.

Dhanagare, D. N. (2013) 'Understanding the new farmers' movement in Maharashtra: Towards an analytical framework', Eastern Anthropologist. Indian Institute of Advanced Study, Shimla, India: Serials Publications, 66(2-3), pp. 163-217. Available at: https:/ / w w w . s c o p u s. c o m / i n w a r d / r e c o r d . u ri ? e i d = 2-s 2 . 0 84904686819\&partnerID=40\&md5=bbf8d339e0ba67b55019e57a6ef0e265. 
Dhanagare, D. N. (2014) 'Selective Appropriation of Gender Ideology: Mahila Aghadi of the Farmers' Movement in Maharashtra (1986-2004)', History and Sociology of South Asia. Indian Institute of Advanced Studies, Shimla, India: SAGE Publications Ltd, 8(2), pp. 157-194. doi: 10.1177/2230807514524046.

Dixon-Woods, M. et al. (2006) 'How can systematic reviews incorporate qualitative research? A critical perspective', Qualitative Research, 6(1), pp. 27-44. doi: 10.1177/ 1468794106058867.

Dubois, O. (2008) 'Making sure that biofuel development benefits small farmers and communities', Unasylva. Climate Change and Bioenergy Division, Natural Resources Management and Environment Department, FAO, Rome, Italy, 59(230), pp. 25-32. Available at: https://www.scopus.com/inward/record.uri?eid=2-s2.069949171638\&partnerID=40\&md5=bb93fc058ef3131fa30632cad45656d8.

Falnikar, A. and Dutta, M. J. (2019) 'Voices of Farmer-Widows Amid the Agrarian Crisis in India', Women's Studies in Communication. Department of Communications and New Media, National University of Singapore, Singapore: Routledge, 42(4), pp. 432-451. doi: 10.1080/07491409.2019.1669756.

Freedman, D. A. et al. (2016) 'Systematic Review of Factors Influencing Farmers' Market Use Overall and among Low-Income Populations', Journal of the Academy of Nutrition and Dietetics. Prevention Research Center for Healthy Neighborhoods, Case Western Reserve University, Cleveland, OH, United States: Elsevier, 116(7), pp. 1136-1155. doi: 10.1016/j.jand.2016.02.010.

Futemma, C., De Castro, F. and Brondizio, E. S. (2020) 'Farmers and Social Innovations in Rural Development: Collaborative Arrangements in Eastern Brazilian Amazon', Land Use Policy. State University of Campinas (UNICAMP), Center for Environmental Study and Research (NEPAM), Campinas, SP, Brazil: Elsevier Ltd. doi: 10.1016/ j.landusepol.2020.104999.

Gordon, R. (1999) 'Poisons in the fields: The United Farm Workers, pesticides, and environmental politics', Pacific Historical Review. University of California Press, 68(1), pp. 51-77. doi: 10.2307/3641869.

Hasan, Z. (1994) 'Shifting Ground: Hindutva Politics and the Farmers' Movement in Uttar Pradesh', The Journal of Peasant Studies. Centre for Political Studies, School of Social Sciences, Jawaharlal Nehru University, New Delhi-110067, India, 21(3-4), pp. 165194. doi: 10.1080/03066159408438558.

Herring, R. J. (2007a) 'Stealth seeds: Bioproperty, biosafety, biopolitics', Journal of Development Studies. Cornell University, Ithaca, NY, United States, 43(1), pp. 130157. doi: 10.1080/00220380601055601.

Herring, R. J. (2007b) ‘The genomics revolution and development studies: Science, poverty and politics', Journal of Development Studies. Cornell University, Ithaca, NY, United States, 43(1), pp. 1-30. doi: 10.1080/00220380601055502. 
Herring, R. J. (2015) 'Politics of biotechnology: Ideas, risk, and interest in cases from India', AgBioForum. Cornell University, United States: University of Missouri, 18(2), pp. 142155. Available at: https://www.scopus.com/inward/record.uri?eid=2-s2.084950269428\&partnerID $=40 \& m d 5=1412 d 202$ ecbfe5594e8203ed3402357c.

Hiller, H. H. (1975) 'A reconceptualization of the dynamics of social movement development', Sociological Perspectives. University of Calgary, Canada, 18(3), pp. 342360. doi: $10.2307 / 1388434$.

Hinrichs, C. C. and Allen, P. (2008) 'Selective patronage and social justice: Local food consumer campaigns in historical context', Journal of Agricultural and Environmental Ethics. Department of Agricultural Economics and Rural Sociology, The Pennsylvania State University, University Park, PA 16802, United States, 21(4), pp. 329-352. doi: 10.1007/s10806-008-9089-6.

Khoo-Lattimore, C., Mura, P. and Yung, R. (2019) 'The time has come: a systematic literature review of mixed methods research in tourism', Current Issues in Tourism. Taylor \& Francis, 22(13), pp. 1531-1550. doi: 10.1080/13683500.2017.1406900.

Leite, J. G. D. B., Silva, J. V and van Ittersum, M. K. (2014) 'Integrated assessment of biodiesel policies aimed at family farms in Brazil', Agricultural Systems. Plant Production Systems, Wageningen University, P.O. Box 430, 6700 AK Wageningen, Netherlands: Elsevier Ltd, 131, pp. 64-76. doi: 10.1016/j.agsy.2014.08.004.

Levien, M. (2013) 'The Politics of Dispossession: Theorizing India's "Land Wars"', Politics and Society. Johns Hopkins University, United States, 41(3), pp. 351-394. doi: 10.1177/ 0032329213493751.

Lindberg, S. (1994) 'New Farmers' Movements in India as Structural Response and Collective Identity Formation: The Cases of the Shetkari Sanghatana and the BKU', The Journal of Peasant Studies. Department of Sociology, University of Lund, Box 114, 221 00, Lund, Sweden, 21(3-4), pp. 95-125. doi: 10.1080/03066159408438556.

Makita, R. (2016) 'A Role of Fair Trade Certification for Environmental Sustainability', Journal of Agricultural and Environmental Ethics. Graduate School of Social Design Studies, Rikkyo University, Toshima-ku, Tokyo, Japan: Springer Netherlands, 29(2), pp. 185-201. doi: 10.1007/s10806-016-9604-0.

Mooney, P. H. (2004) 'Democratizing rural economy: Institutional friction, sustainable struggle and the cooperative movement', Rural Sociology. Department of Sociology, University of Kentucky, Lexington, KY 40506-0027, United States: Rural Sociological Society, 69(1), pp. 76-98. doi: 10.1526/003601104322919919.

Navajas-Romero, V., Del Río, L. C. Y. L. and Ceular-Villamandos, N. (2020) 'Analysis of wellbeing in nongovernmental organizations' workplace in a developed area context', International Journal of Environmental Research and Public Health. Department of Statistics and Operations Research, Business Organization and Applied Economics, Universidad de Córdoba14014, Spain: MDPI AG. doi: 10.3390/ijerph17165818. 
Nicolas, J. et al. (2018) 'On the risks and safeguards for requirements engineering in global software development: Systematic literature review and quantitative assessment', IEEE Access, 6, pp. 59628-59656. doi: 10.1109/ACCESS.2018.2874096.

Pai, S. (2000) 'New social and political movements of details: A study of Meerut district', Contributions to Indian Sociology. Centre for Political Studies, School of Social Sciences, Jawaharlal Nehru University, New Delhi 110 067, India: Sage Publications India Pvt. Ltd, 34(2), pp. 189-220. doi: 10.1177/006996670003400202.

Patnaik, A., Jongerden, J. and Ruivenkamp, G. (2018) 'Rights or ability: Access to plant genetic resources in India', Journal of World Intellectual Property. Sociology and Anthropology of Development, Wageningen University, Wageningen, Netherlands: Blackwell Publishing Ltd, 21(3-4), pp. 157-175. doi: 10.1111/jwip.12102.

Prentice, C., Chen, J. and Wang, X. (2019) 'The influence of product and personal attributes on organic food marketing', Journal of Retailing and Consumer Services. Griffith Business School, Griffith University, Brisbane, Australia: Elsevier Ltd, 46, pp. 70-78. doi: 10.1016/j.jretconser.2017.10.020.

Prost, S. et al. (2019) 'Infrastructuring food democracy: The formation of a local food hub in the context of socio-economic deprivation', Proceedings of the ACM on HumanComputer Interaction, 3(CSCW). doi: 10.1145/3359159.

Roy, H., Hall, C. M. and W. Ballantine, P. (2017) 'Trust in local food networks: The role of trust among tourism stakeholders and their impacts in purchasing decisions', Journal of Destination Marketing and Management. Elsevier Ltd, 6(4), pp. 309-317. doi: 10.1016/ j.jdmm.2017.07.002.

Sengers, F., Wieczorek, A. J. and Raven, R. (2019) 'Experimenting for sustainability transitions: A systematic literature review', Technological Forecasting and Social Change. Elsevier Inc., 145(September), pp. 153-164. doi: 10.1016/j.techfore.2016.08.031.

Starr, Amory (2010) 'Local food: A social movement?', Cultural Studies - Critical Methodologies, 10(6), pp. 479-490. doi: 10.1177/1532708610372769.

Starr, A (2010) 'Local food: A social movement?', Cultural Studies - Critical Methodologies. Sociology, University of California-Santa Barbara, PO Box 1198, Venice, CA 90294, United States, 10(6), pp. 479-490. doi: 10.1177/1532708610372769.

Tomlinson, I. (2008) 'Re-thinking the transformation of organics: The role of the UK government in shaping British organic food and farming', Sociologia Ruralis. Centre for Environmental Policy, Imperial College London, Exhibition Road, South Kensington, London SW7 2AZ, United Kingdom, 48(2), pp. 133-151. doi: 10.1111/ j.1467-9523.2008.00457.x.

Tripp, W. B. (2018) 'Being green: Patterns of participation in the environmental movement', Current Sociology. University of West Georgia, United States: SAGE Publications Ltd, 66(5), pp. 788-809. doi: 10.1177/0011392117737818. 
De Weerd, M. and Klandermans, B. (1999) 'Group identification and political protest: Farmers' protest in the Netherlands', European Journal of Social Psychology, 29(8), pp. 1073-1095. doi: 10.1002/(sici)1099-0992(199912)29:8<1073::aid-ejsp986>3.0.co;2-k.

Wegren, S. K. (1996) 'The politics of private farming in Russia', Journal of Peasant Studies. Department of Political Science, Southern Methodist University, Dallas TX 75275, United States: Frank Cass Publishers, 23(4), pp. 106-140. doi: 10.1080/ 03066159608438621.

Wright, W. and Reid, T. (2011) 'Green dreams or pipe dreams?: Media framing of the U.S. biofuels movement', Biomass and Bioenergy. Department of Community, Agriculture, Recreation, and Resource Studies, Michigan State University, 330B Natural Resources Building, East Lansing, MI 48824-1222, United States, 35(4), pp. 1390-1399. doi: 10.1016/j.biombioe.2010.07.020. 